\title{
Commentary
}

\section{After Practice: A Personal Reflection}

\section{Barbara Czarniawska}

GRI, University of Gothenburg, Sweden

\section{DOI}

10.19154/njwls.v5i3a.4836

y text contains more questions than answers, and the answers are only speculative. My first question is: 'Whose turn to practice took place in 2001?' The text contains a short review of various meanings of the term in different disciplines. From there I move to the second question, which I find especially relevant for my discipline: management and organization studies. 'Is 'reflective practitioner' an oxymoron?' I set Niklas Luhmann against Donald Schön in my search for an answer. The third question is: 'How can bridges between practitioners and theoreticians of management be (re)built?'

\section{My first encounter with 'practice'}

In the early 1970s, economists from Warsaw School of Economics active within the research program 'Functioning, organization and further development of Polish retail' (Beksiak 1978), established contacts with management scholars at the University of Gothenburg. (As usual, these contacts grew from personal connections and interests, which are of no relevance here.) It was partly this encounter that led the project director, Professor Janusz Beksiak, to the conclusion that economic models, this peculiar kind of science fiction, provide no information about the way economic decisions are made in practice. The Swedish colleagues were interested in these specific matters, and in order to continue contacts and exchanges, similar studies had to be made. Alien to fieldwork techniques, Professor Beksiak employed me, a psychologist trained in such approaches, as a methodological consultant (Beksiak and Czarniawska 1977). The results differed dramatically from the predictions of the theoretical models of (socialist) economies; the latter, surprisingly enough, were quite consistent with what was practiced in large US corporations (Czarniawska 1985). For me, the future direction became obvious: Since that first Polish project, I studied managerial practices in the USA, Italy, and Sweden.

Imagine my surprise in 2001 when I encountered a volume edited by Theodore Schatzki et al., entitled The Practice Turn in Contemporary Theory; it summarized contributions to the 1996 conference 'Practices and Social Order' at the University of Bielefeld. As far as I could see, most of management and organization researchers (with the few exceptions of few scholars who still believed in the design of perfect structures) studied organizing and management in practice. So what was the turn all about? 


\section{Whose practice? Which theory?}

I could see at least three explanations for this surprising 'turn.' The first was linguistic. In Polish, as in Swedish, the term 'practice' is used either as the opposite of 'theory' or as a way of indicating activities of professionals, such as doctors and lawyers. The word 'practices' in plural is a synonym in Polish for various acts of cheating, and in Swedish, depending on the accent, it means 'practitioners.' Thus both Swedes and Poles often used the Latin-German 'praxis' to describe what we studied. (Observe that in English common usages of the plural are quite similar.) Thus 'the turn to practice' could be a linguistic turn in Anglo-Saxon social sciences, where the term would be now used as the equivalent of the German 'praxis' (notice that the conference took place in Bielefeld, and one of the organizers and book editors was Karin Knorr Cetina). ${ }^{1}$

Another reason for announcing the turn could have been related to the fact that the conference participants were sociologists who, like economists, are fonder of theory than of practice. The contribution of a philosopher gave weight and legitimacy to the interest in practice, and French participants in particular had no difficulty in finding predecessors in the pragmatist French thought-from Bourdieu through Callon and Latour to Boltanski and Thévenot. Thus for the French scholars 'the practice turn' was at least two decades old, but in 1996/2001 it finally reached Anglo-Saxon waters.

The third reason could be that most social sciences and writers in most languages have long used the term 'practice' and 'practices,' but with many different meanings, contributing to obfuscation rather than enlightenment. Such, at least, was the opinion of Paul Rabinow, which I found instructive:

Although the theme of 'practice' has been central to American cultural anthropology for almost a decade now, it is rarely defined with any rigor. Sherry Ortner (1984: 149) makes this point: 'What is a practice? In principle, the answer to this question is almost unlimited: anything people do. Given the centrality of domination in the model, however, the most significant forms of practice are those with intentional or unintentional political implications. Then again, almost anything people do has such implications. So the study of practice is after all the study of all forms of human action, but from a particular-political-angle.' I take a different approach, one that is less general and that takes up practices from a different angle, the ethical rather than the political. (Rabinow 1997, p. 195)

In order to elaborate his ethical approach, Rabinow supported his argument with Alasdair MacIntyre's (1981, p. 187) definition of practice:

(...) any coherent and complex form of socially established cooperative human activity through which goods internal to that form of activity are realized in the course of trying to achieve those standards of excellence which are appropriate to, and partially definitive of that form of activity, with the result that human powers to achieve excellence, and human conceptions of the ends and goods involved, are systematically extended. Tic-tac-toe is not an example of a practice in this sense, nor is throwing a football with skill; but the game of football is, and so is chess. 
Rabinow thus commented on MacIntyre's definition:

The language of the definition is full of terms (form, coherence, excellence, and so forth) one rarely if ever finds in contemporary social sciences. The reason for this unfamiliarity is that MacIntyre draws his terms from an older vocabulary and tradition, one that exists today as a minor current in moral philosophy, that of the virtues. (Rabinow 1997, p. 195)

Although I have some fear of stepping up on the high horses of a political and/or ethical stance (as a student of a practice of management-another way of limiting the term-I have neither a political nor a moral mandate to do so), I am fond of MacIntyre's definition because it engages this aspect of the term 'practice' that in fact has to do with striving for excellence: 'You need to practice more'; 'She must yet do her daily practice,' but sets it firmly in a social context (throwing ball skillfully is not an example of a practice; the game of ball is). I use it in a shortened version: 'any coherent and complex form of socially established cooperative human activity through which goods internal to that form of activity are realized in the course of trying to achieve those standards of excellence which are appropriate to, and partially definitive of that form of activity.' But, one may ask, what about non-humans? Are they to be out of the picture once more?

\section{A turn to practice in an ANT-ian mode}

In the introduction to The Practice Turn in Contemporary Theory, Schatzki wrote:

... there is no unified practice approach. Most thinkers who theorize practices conceive of them, minimally, as arrays of activity. Not only, however, do their conceptions of activity and what connects activities vary, but some theorists define practices as the skills, or tacit knowledges and presuppositions, that underpin activities (e.g. Turner 1994; Dreyfus 1991). Most theorists, moreover, above all those in philosophy and the traditional social sciences, identify the activities involved as those of persons: practices are arrays of human activity. A significant 'posthumanist' minority centered in science and technology studies avers, however, that the activities bound into practices also include those of nonhumans such as machines and the objects of scientific investigation. (Schatzki 2001, p. 2)

In the remainder of the text, Schatzki acknowledged the point made by the 'posthumanist minority': 'A central core (...) of practice theorists conceives of practices as embodied, materially mediated arrays of human activity centrally organized around shared practical understanding' (ibid.) And perhaps even MacIntyre's definition can be reconciled with the precepts of scholars of science and technology that insist on a symmetric treatment of all 'actants'-human and nonhuman agents-involved in an activity (see, e.g., Latour 1993).

As I see it, MacIntyre's practice is certainly realized with the cooperation of things and machines; yet a question remains if the vocabulary of virtues can be applied to machines as well. It has certainly been used in this way in science fiction, where robots, avatars, and computers can be 'excellent' and 'evil'; ANT (actor-network theory) has its roots in narratology, so why not? Notice also that MacIntyre (who demonstrated a great interest in the phenomenon of modern management) plays in his definition on 
the meaning of the word 'goods.' A practice may produce concrete effects in terms of material products, even commodities 'goods,' but these products also have a moral or aesthetic value: they must be 'good.' It is the practitioners who define-and redefine through practice-the meaning of 'good.' One can imagine that the concept of 'good' as conceived by classical musicians differs from that shared by rappers. Machines can evaluate human performance, and vice versa. If the quest for betterment can be seen as human, certain aspects of performance-the ability to compute complex calculations instantly, for example-belong only to machines. Machines can be good; they can be excellent; they can be improved upon; they also can evaluate human performance in the same terms (although usually put in a numerical form). The symmetry is maintained, but symmetrical parts need not be identical. What is important is, on the one hand, MacIntyre's emphasis on the necessary sociality of practice, an emphasis that is also central to ANT type of approaches; and, on the other, his introduction of the vocabulary of virtues, absent from ANT. Yet 'goodness' and 'excellence' are key aspects of the common human and non-human practices.

As I pointed out at the outset, whereas the symmetry requirement was a novelty in management and organization studies, the turn to practice was not. What plagues the contemporary scholarship in my discipline is the growing chasm between theory and practice. To put it bluntly, the discipline (if this hybrid field deserves such a label) that was founded on the assumption of the utility of its theory to management practice is now increasingly ignored by the practitioners, who prefer to listen to consultants' storytelling than to theories, no matter how practice oriented.

\section{Is 'reflective practitioner' an oxymoron?}

As I see it, nothing announced such 'turn away from theory.' Kurt Lewin's dictum 'There is nothing more practical than a good theory' (1952, p. 169) began to be doubted. Was the statement wrong, or are theories are not good enough? Argyris and Schön (1974) noted that, in practice, two kinds of theory may operate: 'espoused theories' (those revealed in interviews with practitioners) and 'theories-in-use' (those that can be deduced from observations of actual practices). ${ }^{2}$ While the espoused theories tend to be versions of, or at least allude to, rationalist models of decision making, theories-in-use are more or less descriptions of successful tinkering (in the vocabulary of Knorr Cetina 1981), most often unverbalized by their practitioners.

Managers do reflect-in-action, but they seldom reflect on their reflection-in-action. Hence this crucially important dimension of their art tends to remain private and inaccessible to others. (Schön 1984, p. 243)

Thus Schön suggested that such theories-in-use should be made explicit, and this can be achieved by educating reflexive practitioners (Schön 1987).

But can managers be taught to reflect on their reflection-in-action? According to Niklas Luhmann (1998), only on the condition that the practitioners alternate between acting and reflecting; it is impossible to do both at the same time. The world as seen by actors is necessarily unlike the world seen by observers. Observers are able to see options-and to distinguish among them, but not enough for a decision to act. As many 
studies in my field have shown, the best way to paralyze action is to start a proper decision-making process. Actions stem from resolutions, not from decisions understood as acts of choice. Actors can see diverse options only in the moment of reflection, of observing, of not acting. Schön's way out was the postulate that reflective practitioners must therefore develop 'a double vision' (Schön 1983, p. 164). However, the very awareness of an alternative would be paralyzing: 'Even Buridan's ass, placed, as it were, between two equally tempting bales of hay, will survive, even if it notices that it cannot decide, for that is why it decides nevertheless!' (Luhmann 1995, p. 360). ${ }^{3}$ Contradiction-in life and in science-puts a stop to observation and demands action; observation can be made at a distance only, establishing distinctions until they become paradoxical; then it is time to come closer and start acting.

But even if Luhmann was right and Schön was wrong, it would seem that a neat division of work is still possible: Scholars observe, practitioners act; scholars point out paradoxes, practitioners deparadoxify (Czarniawska 1997); scholars offer feedback that helps practitioners to improve their action, to achieve 'their standards of excellence.' So, why consultants instead of theoreticians? Are their theories 'better?'

Niklas Luhmann (1989/2005) was one of the few theoretical sociologists who paid any serious attention to management consultants (perhaps because he experienced management practice himself?). Still, he doubted if the messages delivered by consultants arrive to clients in the form in which they were sent, whether they claim to deliver a theory or to instigate a practice. He questioned the possibility of a successful communication between consultants and their clients, as, in his view, their acts of communication form two distinct and closed systems. Such systems can only reproduce themselves, according to their blueprint, or 'DNA'-thus the term 'autopoiesis.' Although all energy systems are open systems (there is no perpetuum mobile), all communication systems are autopoietic (Luhmann 1995).

A communicative event consists of information, utterance, and meaning. Although the information transmitted and received may be identical, and although all parties may perceive the fact of the utterance, the meaning will be produced (a sense will be made of the utterance) within the system. Such internal communications can concern only what belongs to the system itself. Any communication arriving from the outside would become something else when internally processed (Luhmann 1989/2005). The systems can shout to each other, but what reaches them is but a reflection of their own voices.

That a group of consultants $[\ldots]$ cannot communicate itself completely (but is nonetheless capable of communicating internally about this impossibility of external communication) is due to the fact that communication is the operation by means of which the group carries its own autopoiesis, and thus the means by which it regenerates its own unity, as well as the difference between this unity and its environment. (Luhmann 1989/2005, p. 355)

Seen from this viewpoint, managers and consultants are unable to understand one another; they live in two closed (communication) worlds that never intersect. So, yes, consultants, who see themselves merely as observers of other actors, continue to plough through, unaware of the contradictions between their theories and their practices. They fail to see that they are actors rather than observers of their own practice (Luhmann 1995). Karin Fernler (1993) reported that management consultants interviewed by her study were actually upset by the idea that they should apply their 
advice to their own company. Like every other actor, consultants have a blind spot where their own practice is concerned, but their practices are observed by their clients who, Luhmann has suggested, actually select them on the basis of their blind spots (Luhmann 1989/2005). In fact, the reform program offered by consultants studied by Fernler sold very well.

Furthermore, the unsuccessful communication does not mean that management consulting is useless. According to Luhmann, the attempts at communication produced by management consultants serve as an irritant to the client system. Consultants do not 'know better'; they are able to observe the actors, and see them in another light than the actors when they try to observe themselves. It is this difference in the observation points that can become 'irritating, stimulating, and eventually productive' (Luhmann 1989/2005, p. 364). Left to themselves, clients would be enacting their own visions of the world, perhaps until some crisis stopped them. Irritated by consultants, the clients may themselves arrive at a new and brilliant solution to their problems-solutions that still conform to the main traits of the system. Luhmann has also suggested that successful consultants do not point out blind spots in client's observations, as researchers often attempt to do, but merely emphasize the difference between their observations and those of the clients.

Herein probably lies the difference in success between the two groups of observers: consultants and researchers. As I pointed out in another context, consultants engage in the 'logic of practice, ${ }^{3}$ helping to develop it without ever stating it explicitly. Also, and this in my opinion is very important, they help to formulate representation statements, which actually mask the logic of practice according to the representation rules sanctioned by a given social order. It can be said that they deliver theories to be espoused, in Argyris and Schön's vocabulary. Thus consultants not so much help to improve the practice of management, as to engage in a common practice of legitimization.

A great many researchers (a group to which I belong) do the opposite: attempt to describe what is meant by the practical sense and how it is arrived at (in the hope of provoking reflection that might help in its further development) and lay bare the process of legitimization (Czarniawska 2001). The practitioners are not amused. Perhaps they are right at that: Whereas the implicit knowledge can be made explicit, the explicit formulation of the tacit knowledge is not of much use (pace Schön). Whoever learned to swim by reading the manual? If so, what is the management and organization theory good for?

\section{Management theory and practice at the crossroads}

Over a hundred years ago our forefathers (plus Mary Follet) began forming the subject that later acquired a variety of names; they did so on the promise to solve any problems that companies and administrative organizations might possibly have. Later, this role of 'company doctor' was further developed, especially by the Tavistock Institute, which was given large sums of money by the British government to help all companies facing trouble in post-war Great Britain. Researchers arrived, and like car mechanics or physicians, they examined the 'body' of the organization, made a diagnosis, and prescribed a cure. At the same time, however, this kind of knowledge was becoming a strictly academic subject, with PhDs and professors, refereed journals, and international conferences.

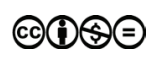


Where is management and organization theory now? Is it a practical subject that produces practitioners and improves practice, or is it an academic discipline eager to establish for itself a decent position within social sciences? Once, when bemoaning a lack of interest from practitioners in front of an US audience, I met with the response that there was nothing to worry about: After all, there are so many doctoral students to teach! The scholars now seem to be divided in three groups: those who opt for the former (teaching practical skills and acting as consultants); those who opt for the latter (addressing themselves only to the academy); and a third group, perhaps the least numerous, comprising those who still have a vision of a hybrid discipline in close contact with practice-not with the purpose of dictating the order of things, but of reflecting and provoking via basic research and theory.

Certainly, the 'company doctor's' role needs to be redefined. After all, it is a strange idea that researchers from outside an organization can tell practitioners how to run their companies and how to be better managers; that these 'experts' are expected to reform and reorganize living organizations. If researchers are so good at organizational action, one might well ask why they are wasting their talents on academia. And yet this assumption has persisted since the birth of this discipline. The discipline had, after all, made an oath to its practical utility. Does it still hold?

When Plato laid the foundations for western philosophy, he promised the Athenian politicians to solve any problem that might arise: from guidelines as to how to conquer Sparta to methods for raising one's sons (no feminist, our Plato). When Durkheim laid the foundations for modern sociology, he promised to solve every problem of French society, from German neighbors to poverty and crime. Both disciplines have ended up at an advanced theoretical stage while the practical problems have multiplied, if anything. Should one conclude that all those promises were hypocritical, made with the intention of justifying oneself to society on false premises?

Indeed they were a means of justification (all practices must be legitimate in democratic societies); however, those promises were born not out of hypocrisy, but out of enthusiasm and naiveté-so typical of the coming into existence of new ways of thinking. That which once was enthusiasm and exalted optimism, with time turns into frustration if things go wrong, and wisdom if things go right. Full of optimism, I wrote on the subject in 1999:

Things have gone rather well for business and management sciences, which means that we are now in the position to afford some reflection upon what we are doing and why. If we are a practical subject devoid of intellectual ambition, then it is time to stop wasting society's funds: back to schools of commerce and to two-month correspondence courses in accounting and business techniques. If we are an academic discipline however, we must ask ourselves what could be our contribution to the general debate concerning the desired shape of our society in the twenty-first century. (Czarniawska 1999, pp. 6-7)

At that time, I believed that the desired direction lay in further legitimization of the reflection on practice (Czarniawska 2001). After all, such reflection is already legitimate in art and literature, where insightful descriptions of the process of creation are as valid as stylized stories. Such legitimation, I believed, requires a further development of the theory of practice.

I am no longer sure about this. 'A further development of the theory of practice' may mean a further step away from the practice of management, toward increased abstraction 
and the continued autopoiesis of the practice of theory. While inevitable (science is as autopoietic as any other communication system), the increased abstraction does not have to be all there is. The DNA of the social sciences is richer than that. I still believe in my second recommendation from a decade ago- that of a redefinition of the role of the field researchers. When in the field, they could act as kind of therapists, facilitating the practitioners' self-reflection-possibly as irritants, just like professional consultants. Their reports, however, and herein lies the novelty, would not be targeted at the same group of practitioners. As Latour (1993) pointed out, if one's fieldwork was done well, the practitioners already knew what was written, even if before this knowledge was only that tacit reflection Schön spoke about. The researchers' aim would be to show how both the practical sense and the representations of a given practice are being constructed and/or acquired, so that other practitioners (including researchers) could learn from such 'stories from afar.' It would obviously have a demystifying effect, but not all practitioners wish to remain mystified.

The present irritation of practitioners seems to stem from their conviction that revealing the construction of representation would be damaging to their legitimation attempts. Such were the fears expressed by some natural scientists when the sociology of science and technology started to describe how they produce facts in their laboratories (Knorr Cetina 1981; Latour and Woolgar 1979/1986). It does not seem, however, that the financing of laboratories diminished after such works became accessible, while the general understanding of 'laboratory work' significantly increased. There appears to exist a vicious circle of underestimating 'the Other': Managers think politicians must remain under the illusion, politicians think the voters must remain under the illusion, researchers think practitioners should remain under the illusion, and journalists think we all should remain under the illusion that the world is simpler than it is. According to my proposal, theoreticians will be offering a picture of a practice that will enrich a general knowledge of that practice, rather than competing with consultants in trying to improve it directly.

I am not sure that it will work. My hope lies still with the analogy to literature. I strongly doubt that the writers learn to write better from reading literary criticism, but I know that readers reach for it seeking help and guidance in their choices. And as a 'critical management theory' already exists, I need to specify what I mean by criticism. The adjective 'critical' has in English two meanings:

crit-i-cal (adj)

1. tending to find fault with a particular person or thing, or with people and things in general

2. containing or involving comments and opinions that analyze or judge something, especially in a detailed way (http://encarta.msn.com/encnet/features/dictionary/DictionaryResults.aspx ? lextype $=3 \&$ search $=$ critical $)$

I opt for the second meaning of the word (Czarniawska 2010). My favorite analogy is that between a management researcher and a theater critic:

We can opt for what we ourselves like best, or prompt the directors to keep the public happy, or to keep it on its toes. In the long run, however, we should be able to present some more systematic reflections on the organizational theatre. It would be interesting to be able to follow the rise and the fall of the 'favourites' in the social consciousness, to see when 
and how people reach into the repertoire of roles to exchange the last favorite for a new one. Organization research can try to evaluate contemporary performances and to build a theory of organizational theatre in a historical perspective. (Czarniawska 1993/2006, p. 44)

Such a stance requires a closeness to the practice of management, while keeping enough distance in order to be able to problematize it, rather than theorizing it still further. Remember the non-negligible hostility of both writers and critics to the 'literary theory.' By offering 'stories from afar,' management scholars may be of help-to managers and their subordinates-in shaking free from absurdities that are not of their making, and in justifying the seeming absurdities that are of their making. By presenting the accurate and detailed images of managerial practices taken from the field to the general public, management scholars may help young people to decide about their future careers-perhaps as worthy an achievement as striving to become a 'company doctor'-if not as lucrative.

\section{References}

Argyris, C., Putnam, R. W., and Smith, D. M. (1985) Action Science: Concepts, Methods, and Skills for Research and Intervention. San Francisco, CA: Jossey-Bass.

Argyris, C., and Schön, D. (1974) Theory in Practice: Increasing Professional Effectiveness. San Francisco, CA: Jossey-Bass.

Beksiak, J. (ed.) (1978) Zarzadzanie przedsiębiorstwami-uczestnikami rynku dóbr konsumpcyjnych [Managing enterprises acting on the consumers' market]. Warszawa: PWN.

Beksiak, J. and Czarniawska, B. (1977) 'Enterprise Response Patterns Under the Socialist Management System. Oeconomica Polona, 2: 211-228.

Bourdieu, P. (1990) The Logic of Practice. Cambridge, UK: Polity Press.

Czarniawska, B. (1985) Controlling Top Management in Large Organisations: Poland and U.S.A. Aldershot: Gower.

Czarniawska, B. (1993/2006) The Three-Dimensional Organization. Lund: Studentlitteratur.

Czarniawska, B. (1997) Narrating the Organization. Dramas of Institutional Identity. Chicago, IL: The University of Chicago Press.

Czarniawska, B. (1999) Writing Management. Organization Theory as a Literary Genre. Oxford: Oxford University Press.

Czarniawska, B. (2001) 'Is It Possible to Be a Constructionist Consultant?' Management Learning, 32(2): 253-266.

Czarniawska, B. (2010) 'How Critical Does the Management Research Need to Be? Critical Policy Studies, 4(4): 417-418.

Fernler, K. (1993) 'The Reform Principle, Realities and Mediating Concepts. In: Brunsson, N. and Olsen, J. P. (eds.) The Reforming Organization. London: Routledge, 88-108.

Knorr Cetina, K. (1981) Manufacturing Knowledge. An Essay on Constructivist and Contextual Nature of Science. Oxford: Pergamon Press.

Latour, B. (1993) We Have Never Been Modern. Cambridge, MA: Harvard University Press.

Latour, B. and Woolgar, S. (1979/1986) Laboratory Life. Princeton: Princeton University Press.

Lewin, K. (1952) Field Theory in Social Science: Selected Theoretical Papers by Kurt Lewin. London: Tavistock.

Luhmann, N. (1989/2005) 'Communication Barriers in Management Consulting. In: Seidl, D. and Becker, K. H. (eds.) Niklas Luhmann and Organization Studies. Malmö/Copenhagen: Lober/CBS Press, 351-364.

Luhmann, N. (1995) Social Systems. Stanford, CA: Stanford University Press. 
Luhmann, N. (1998) Observations on Modernity. Stanford, CA: Stanford University Press.

MacIntyre, A. (1981) After Virtue. A Study in Moral Theory. Notre Dame, IN: University of Notre Dame Press.

Rabinow, P. (1997) 'Science as a Practice. The Higher Indifference and Mediated Curiosity'. In: Downey, G. L. and Dumit, J. (eds.) Cyborgs \& Citadels: Anthropological Interventions in Emerging Sciences and Technologies. Santa Fe, NM: School of American Research Press, 193-208.

Schatzki, T. R. (2001) 'Introduction: Practice Theory.' In: Schatzki, T. R., Knorr Cetina, K., and von Davigny, E. (eds.) The Practice Turn in Contemporary Theory. London: Routledge, 10-23.

Schatzki, T. R.; Knorr Cetina, K., and von Savigny, E. (eds.) (2001) The Practice Turn in Contemporary Theory. London: Routledge.

Schön, D. (1984) The Reflective Practitioner. How Professionals Think in Action. New York: Basic Books.

Schön, D. (1987) Educating the Reflective Practitioner: Toward a New Design for Teaching and Learning in the Professions. San Francisco, CA: Jossey-Bass.

\section{End notes}

${ }^{1}$ At the "Practice-based theory" seminar (Warwick Business School, 3-5 September 2014) where this text was first presented, Theodore Schatzki told me that the title of their book was chosen by the publisher, in spite of the protests of the editors.

${ }^{2}$ Later, Argyris et al. (1985, p. 81) suggested an interesting distinction, which they did not develop further. Theories of action held by the actors are theories of control ('how to'); theories of action composed by observers are theories of explanation ('how do').

${ }^{3}$ Here, Schön would have disagreed, but he did notice the tendency of systems to self-reproduce themselves. Thus the need for the special training-or for the consultants' help.

${ }^{4}$ It needs to be pointed out that although the title of Bourdieu's book in English is The Logic of Practice (1990), the French book has a title Le sens pratique (1980), quite another matter, in my reading. Thus it can be said that consultants do not instruct practitioners in the logic of practice, but train their practical sense. 